https://doi.org/10.52058/2786-4952-2021-5(5)-861-871

Яценко Тетяна Володимирівна кандидат психологічних наук, доцент кафедри педагогіки та психології Дошкільної освіти, Кременчуцький педагогічний коледж імені А. С. Макаренка, вул. Лізи Чайкіної, 33, м. Кременчук, 39600, тел.: (0670 748-02-33, e-mail: ya.tanya@i.ua, https://orcid.org/0000-0002-5606-1713

Сергіснко Дарина Ігорівна здобувач освітнього рівня бакалавр за спеціальністю 013 «Початкова освіта», Кременчуцький педагогічний коледж імені А. С. Макаренка, вул. Лізи Чайкіної, 33, м. Кременчук, 39600, тел.: (068) 697-35-35, e-mail: daryna.serhiienko@gmail.com

\title{
ОСОБЛИВОСТІ ПРОЯВУ ПРОКРАСТИНАЦЇ̈ У СТАРШОМУ ЮНАЦЬКОМУ ВІЦІ
}

Анотація. У статті описано феномен прокрастинації - систематичне відкладання людиною важливих справ, незважаючи на можливі негативні наслідки для особистості. Представлено науково-теоретичне обгрунтування та всебічне емпіричне вивчення проблеми прокрастинації з точки зору стійкої особистісної конструкції. Визначено сутність академічної прокрастинації як психолого-педагогічної проблеми. Доведено, що зволікання дійсно потребує детального дослідження. Виявляється, що саме навчально-виховний процес характеризується умовами, в яких найчастіше виникає прокрастинація. У роботі описано структуру особистості, схильної до прокрастинації та визначено п`ять компонентів, які iї характеризують (біологічний, мотиваційний, когнітивний, емоційний та поведінковий). На основі проведених експериментальних досліджень визначено компоненти, критерії та описано показники прояву прокрастинації різних рівнів (високого, середнього та низького). Підібрано комплекс психолого-діагностичних методик та досліджено рівень прояву прокрастинації у юнацького віку. Висвітлено результати дослідження рівня прояву прокрастинації. Доведено, що зволікання в середовищі юнаків досить поширене явище, а прокрастинація може бути зумовлена високою особистісною тривожністю, високою мотивацією до уникнення невдач. Представлено основні причини та чинники виникнення прокрастинації. Показано, які особистісні складові впливають на рівень прокрастинації, і якими особливостями характеризується той чи інший рівень прокрастинації. Надана характеристика особистості, яка схильна до відкладання важливих справ на потім. Описано результати проведеного гендерного аналізу та аналізу прояву прокрастинації у респондентів молодшого та старшого юнацького віку. Автор підкреслює та наголошує на 
тому, що названа тема потребує подальшого і більш глибокого дослідження.

Ключові слова: прокрастинація, зволікання, академічна прокрастинація, юнацький вік, показники, критерії та рівні прояву прокрастинації, гендерний аналіз.

Yatsenko Tetyana Volodymyrivna Candidate of Psychological Science, Associate Professor of Educators and Psychology of Preschool Education, A.S.Makarenko Teachers' Training College of Kremenchuk, Lizy Chaikinoi St., 33, Kremenchuk, 39600, tel.: (067) 748-02-33, e-mail: ya.tanya@i.ua, https://orcid.org/0000-0002-5606-1713

Sergiyenko Daryna Ihorivna Candidate of educational level bachelor's degree 013 «Primary Education», A.S.Makarenko Teachers' Training College of Kremenchuk, Lizy Chaikinoi St., 33, Kremenchuk, 39600, tel.: (068) 697-35-35, e-mail: daryna.serhiienko@gmail.com

\title{
PECULIARITIES OF PROCRASTINATION IN SENIOR ADOLESCENT
}

\begin{abstract}
The article describes the phenomenon of procrastination - the systematic postponement of important human affairs despite the possible negative consequences for the individual. The scientific and theoretical substantiation and comprehensive empirical study of the problem of procrastination from the point of stable personal construction are presented. The essence of academic procrastination as a psychological and pedagogical problem is determined. It has been proven that procrastination needs detailed research. It turns out that it is the educational process that is characterized by the conditions in which procrastination most often occurs. The article describes the structure of a person prone to procrastination and identifies five components that characterize it (biological, motivational, cognitive, emotional, and behavioral). On the basis of the conducted experimental researches components, criteria are defined and indicators of manifestation of procrastination of various levels (high, average, and low) are described. A set of psychological and diagnostic methods has been selected and the level of procrastination in adolescence has been studied. The results of the study of the level of procrastination are highlighted. It has been proven that procrastination is quite common among young people, and procrastination can be caused by high personal anxiety, high motivation to avoid failure. The main causes and factors of procrastination are presented. It is shown which personal components influence the level of procrastination, and which features characterize this or that level of procrastination. The characteristic of the person who is inclined to postpone important affairs for later is given. The results of the conducted gender analysis and analysis of procrastination in younger and older adolescents are described. The author emphasizes that this topic needs further and deeper research.
\end{abstract}


Keywords: procrastination, postponement, academic procrastination, adolescence, indicators, criteria and levels of procrastination, gender analysis.

Постановка проблеми. Наукові дослідження останніх років переконливо доводять, що вивчення особливостей прояву прокрастинації в юнацькому віці $€$ досить актуальними. Так, найбільший відсоток прокрастинаторів спостерігається в студентському середовищі, i майже 95\% студентів відзначають, що відкладають виконання саме навчальних обов'язків. Проблема прокрастинації полягає в тому, що вона негативно впливає i на результативність навчання, і на особистісну ефективність та психоемоційний стан людей.

Проблема прокрастанації особистості в юнацькому віці у нині існуючому стандарті успішної особистості набуває особливої наукової й практичної актуальності. Досліджено, що проблема зволікання в середовищі юнаків поширена значно більше, ніж серед працюючих осіб, а прокрастинація може бути зумовлена високою особистісною тривожністю, високою мотивацією до уникнення невдач.

У дослідженнях Р. Классен встановив зв’язок між прокрастинацією, самомотивацією, навчальними досягненнями, самооцінкою та ефективністю особистої самомотивації. За результатами дослідження зроблено висновок, що прокрастинація $є$ мотиваційною проблемою, для подолання якої необхідно досягти достатньо високого порогу мотиваційної автономії.

Аналіз останніх досліджень і публікацій. Дослідженню феномену прокрастинації у вітчизняній науковій літературі присвячені праці Є. Базики, Д. Бикова, М.Дворник, К. Фоменко, спроби дослідити академічну прокрастинацію були здійснені А. Шиліною, К. Мей, М. Шиманською, Н. Карловською, Н. Яакуб, Я. Варваричевою. За результатами дослідження Д. Стеценко, Т. Мотрук, поведінкова затримка проявляється в діяльності, відповідно вона властива лише особистості і тягне за собою негативні наслідки. Основною причиною прокрастинації, на погляд Т. Колтунович та О. Поліщук, є уникнення дискомфорту та прагнення до задоволення «тут i зараз». У сучасній психології зволікання розуміється як негативний феномен. Наприклад, Л. Дементій розглядає нездатність володіти ситуацією як наслідок прокрастинації, а К. Лей синонімізує їі 3 «пасивністю, песимістичністю i дезадаптацією», Ф. Семенова підкреслює, що прокрастинація часто стає формою прихованого протесту підлітка, і може залишитися такою для людини будь-якого віку, коли виконання завдання сприймається як згоду з порушенням меж психологічного простору особистості.

Мета статті - дослідження особливостей проявів прокрастинації у юнацькому віці.

Виклад основного матеріалу. Термін «прокрастинація» 3'явився в психології відносно недавно. Вперше його використав П. Рінгенбах у 1977 р. у книзі «Прокрастинація в житті людини». Після нього В. Кнаус та А. Елліс у 
Журнал«Герспективитаінновації наукиљ

(Серія«Гедагогіка»), Серія«ГТихологія», Серія «Медицина»

№5(5) 2021

роботі «Подолання прокрастинації» та Дж. Берк і Л. Юен у своїй праці «Прокрастинація: що це таке і як 3 нею боротися». Основою обох книг була консультативна практика авторів [1].

У вітчизняній науковій літературі термін «прокрастинація» 3'явився у 1992 році, однак перші згадки про прокрастинацію можна зустріти в народному фольклорі, оповіданнях, байках, романах. Відображення прокрастинації можна простежити у народних прислів'ях, таких як: «Не відкладай на завтра те, що можна зробити сьогодні», «Зволікання смерті подібне», «Семеро одного не чекають». У релігійних текстах XVII ст. феномен прокрастинації засуджується як один з тяжких гріхів.

У електронній енциклопедії «Вікіпедія» поняття прокрастинації (від лат. Prōcrāstinātiōo - відкладання на завтра; від prō + crāstinus - завтрашній, від crās - завтра), зволікання розглядають як психологічний термін, що означає схильність людини відкладати неприємні завдання на потім, тяжіння до справ, що приносять більше задоволення або швидший результат. За змістом термін прокрастинація близький до терміну «behavioral delay» (поведінкова затримка) [2].

Прокрастинація - психологічне поняття, означає схильність людини відкладати неприємні рішення і справи на потім, на завтра, на майбутнє, а також учні недооцінюють час або власні ресурси у виконанні завдань і зволікають. Вони частіше не зволікають, коли знають, що отримають винагороду або соціальне визнання.

Автор багатьох праць І. Варваричева розуміє прокрастинацію як «свідоме відстрочення суб'єктами запланованих дій», тобто виділяє усвідомлення як одну з ознак прокрастинації. У сучасній психології прокрастинація загалом розуміється як негативне явище [1].

Відомий науковець К. Лей визначає прокрастинацію як добровільне, нераціональне відкладення запланованих дій, незважаючи на можливий майбутній негативний вплив на особистість. Це означає, що прокрастинація сприймається як диспозиційна, стійка риса особистості [3].

Науковці С. Мохова та А. Неврюєв розглядають зволікання як добровільне нераціональне відкладення бажаних дій на певний проміжок часу, незалежно від наслідків. Наразі не зрозуміло, чи є зволікання тенденцією, чи це лише особливий стан особистості, чи специфічна риса психіки конкретної людини [4].

Відомий науковець Я. Варваричева у своїх дослідженнях наголошує на тому, що прокрастинація або явище зволікання у вітчизняній та західній психології останніми роками вважається моделлю поведінки, а також когнітивним явищем. Науковці піднімають питання про зв'язок між прокрастинацією та різними рисами особистості. Велика увага приділяється вивченню факторів відтерміновування, а також «визначенню» іiі типів, видів, стратегій.

Теоретичний огляд широкого кола досліджень засвідчує, що деякі особи юнацького віку, схильні до систематичного відкладання важливих справ, указаний відсоток різними вченими, коливається в діапазоні від 50 до $95 \%$. 
Перший історичний аналіз феномену прокрастинації було зроблено у 1992 році у роботі Н. Мілграма «Прокрастинація: хвороба сучасності», а широкі наукові дискусії з приводу цього явища почалися двадцятьма роками раніше. Однак згадки про прокрастинацію та описи цього явища можна знайти набагато раніше, зокрема твори часів розквіту промислової революції середини 18 століття в Оксфордському словнику 1548 р. [5].

Дослідженням феномену прокрастинації у вітчизняній науковій літературі займалися вчені Д. Бикова Є. Базики, М. Дворник, К. Фоменко. Також питанням відтерміновування займалися такі вчені: Я. Варваричева, Н. Карловська, К. Мей, А. Шиліна, М. Шиманська, Н. Яакуб.

Науковці Т. Мотрук та Д. Стеценко вважають причинами прокрастинації: перфекціонізм, страх невдачі; страх перед успіхом як додаткові обов'язки, які можуть виникнути в разі успішного виконання завдання; тривожність (особиста та ситуативна); невміння планувати (погана орієнтація у часі, не правильна розстановка пріоритетів справ) [6].

На думку Т. Колтуновича та О. Поліщука, головна причина зволікання уникнення дискомфорту та бажання задоволення «тут i зараз». Всі детермінанти прокрастинації були зведені до двох груп: постійні (стійкі в часі і мають незначні зміни) і ситуаційні (вони виникають випадково і розвиваються під впливом ситуації). Знову ж таки, вони можуть бути: психофізіологічними (темперамент, невротизм тощо), емоційними (тривога, емоційне вигорання, страх тощо), мотиваційними (відсутність мотивації, ситуаційної мотивації тощо), поведінковими (недисциплінованість тощо), джерело (низька компетентність, стан здоров'я тощо); час (нецілеспрямовані терміни, нестача часу тощо) [7].

У деяких дослідженнях зволікання визначають як частково позитивне явище. У цьому випадку відкладення завдання виправдовується зменшенням негативних проявів, що передують йому або супроводжують його виконання. 3 усього вищесказаного можна виділити такі загальні ознаки прокрастинації:

- ірраціональність (суб'єкт заздалегідь знає про негативні наслідки відкладання, але все ж нічого не робить);

- усвідомленість (людина не коригує свої плани, а лише свідомо відкладає намічене раніше);

- негативні емоційні переживання, внутрішній дискомфорт (ця особливість дозволяють розмежувати прокрастинацію і лінь).

Прагнучи виконати завдання за обмежений час, людина відчуває сильні емоційні та фізичні навантаження. Нервове напруження, постійне недосипання, зловживання кофеїном, енергетичними напоями - все це може мати неприємні наслідки для організму. Крім того, зволікання є основою почуття провини за незакінчену роботу, відсутність самореалізації, втрату можливостей тощо, $є$ наслідком слабкого самоконтролю.

Вчений Н. Мілграм та співавтори спочатку виділили 5 типів прокрастинації: 
Журнал«Герспектввита іновації науки

(Серія«Гедагогіка», Серія«ПЕихологія», Серія «Медицина»

№5(5) 2021

1. академічна, тобто відкладення підготовки до контрольних, домашніх завдань;

2. зволікання в прийнятті рішень (у тому числі незначні);

3. компульсивна, яка часто проявляється як хронічне зволікання в будьякій ситуації;

4. невротична, тобто зволікання в життєво важливих рішеннях.

5. побутова або щоденна - нездатність керувати звичайними, регулярними справами (робота по дому, покупка їжі тощо) [8].

Однак пізніше Н. Мілграм у співавторстві з Р. Теннем трансформували цю класифікацію, залишивши лише два типи прокрастинації: відкладання робити завдання і відкладання прийняття рішень [9].

Аналіз наукових джерел показав, що основними причинами прокрастинації дослідники вважають:

- відсутність мотивації до навчання (студенти вступили до ВНЗ лише за бажанням батьків, не бачать перспектив у майбутній професійній діяльності, головною метою навчання є отримання диплома тощо);

- порушення вольової сфери (люди-прокрастинатори - це особистості 3 нерозвиненими, несформованими вольовими процесами, які не вміють чи нездатні перемогти самих себе, подолати труднощі тощо);

- невміння організовувати себе і свій час, підвищений рівень особистісної тривожності, низька самооцінка, слабкість характеру, втома, недостатня готовність до виконання справи, стрес як наслідок невпевненості у своїх силах;

- страх перед майбутнім, успіхом (формується часто ще у шкільні роки та виявляється у прагненні бути гіршим й менш успішним задля збереження певних зв'язків із друзями, відповідати певним стереотипам або ж запобігти додатковим навантаженням та підвищеним вимогам з боку викладачів, батьків тощо).

До факторів, що викликають прокрастинацію е середовищі студента, належать: психологічні, соціально-психологічні, педагогічні та психофізіологічні.

Щодо причин прокрастинації студенти констатували наступне: невміння планувати, брак часу, відсутність мотивації, втома, стан здоров'я, забагато завдань, нецікаві завдання, відсутність волі, наявність інших, більш важливих завдань.

Прокрастинація найчастіше зустрічається у студентів у ситуаціях $\mathrm{i}$ випадках, пов'язаних із інтелектуальним стресом, потребою самоорганізації та планування діяльності, що характеризується несвоєчасною винагородою праці, відсутністю мотивації, потребою у взаємодії з людьми, які викликають негативні емоції. Результатом зволікання є стрес, почуття провини, втрата продуктивності, невдоволення оточуючими через невиконання зобов'язань [9].

Прокрастинатор постійно відкладає виконання плану, і врешті-решт починає виконувати завдання лише тоді, коли настає «дедлайн» - період, після якого марно намагатися надолужити втрачене.

Одним із завдань нашого дослідження було проведення дослідження 3 
питань вивчення особливостей проявів прокрастинації у дітей юнацького віку. Тому ми підібрали психодіагностичні методи, які в повній мірі допоможуть нам вирішити поставлене завдання.

Принцип комплексного, динамічного підходу у вивченні особливостей проявів прокрастинації передбачає вивчення особистості з різних позицій впродовж певного відрізку часу.

Спираючись на структуру прокрастинованої особистості за М. Карлівською та А. Барановою, та дослідження Р. Классена, який зробив висновок, що прокрастинація є мотиваційною проблемою нами було визначено п’ять компонентів, які характеризують прокрастиновану особистість.

Під час проведення дослідження нами було описано не тільки компоненти, а й показники та рівні прояву прокрастинації.

У відповідності до структурних компонентів нами було підібрано ряд психодіагностичних методів, які відповідають названим компонентам:

1. Визначення локалізації контролю.

2. Тест на визначення тривожності.

3. Діагностика мотивацій досягнення.

4. Опитувальник нервово-психічної напруги (НПН).

5. Тест-опитувальник для визначення самоставлення особистості.

Вищеописану інформацію нами було відображено у вигляді структурнологічної схеми (рис.1).

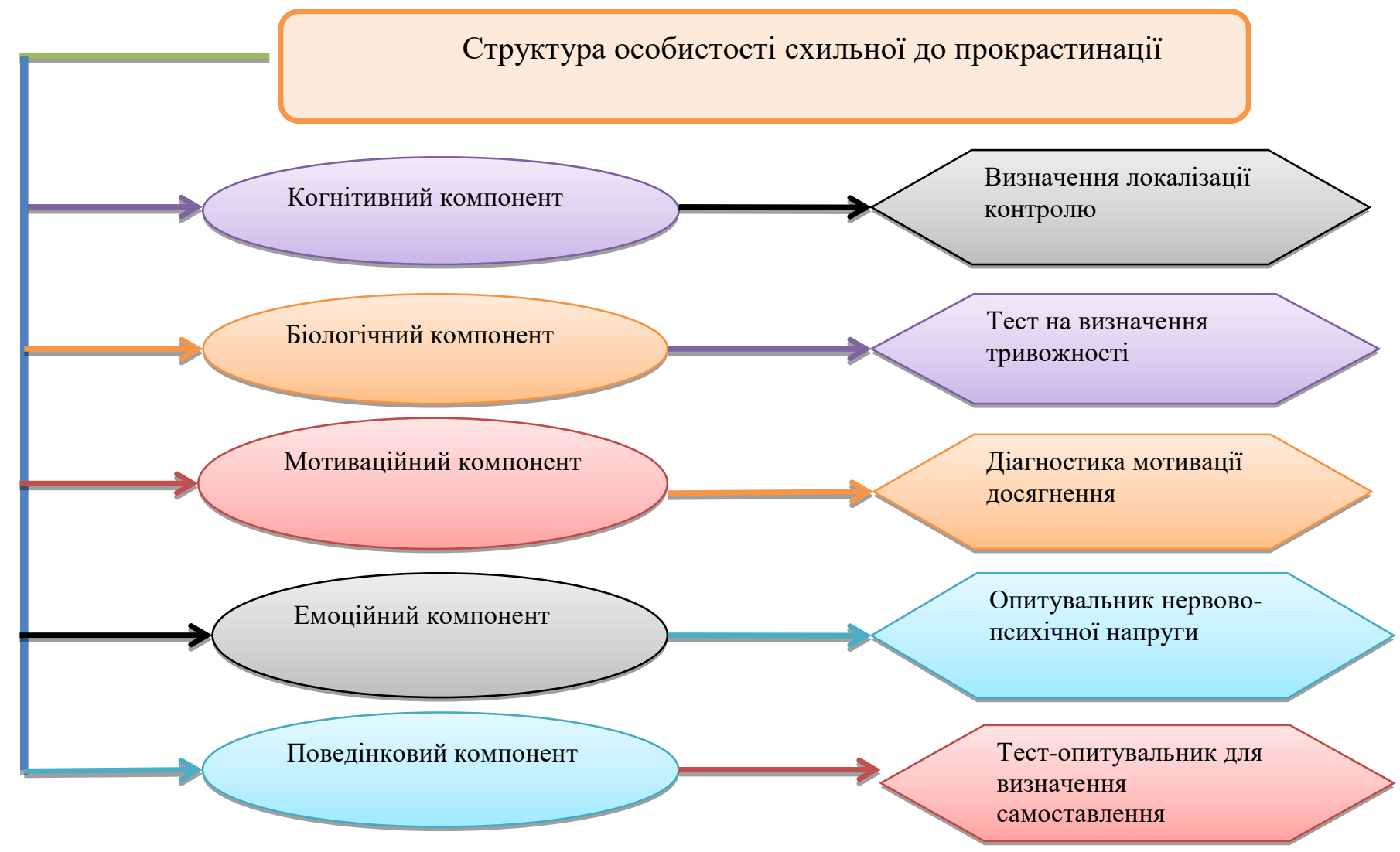

Pис. 1.Структура особистості, схильної до прокрастиначії та методи дослідження 
У дослідженні прийняли участь учні молодшого юнацького віку Наукового ліцею «Політ» при Кременчуцькому педагогічному коледжі імені А. С. Макаренка у кількості (21 хлопчика та 47 дівчат). Також учасниками виступили студенти старшого юнацького віку відділень «Початкової освіти», «Дошкільної освіти» та «Середньої освіти» Кременчуцького педагогічного коледжу імені А. С. Макаренка у кількості (21 хлопчика та 47 дівчат). В цілому у досліджені прийняли участь (68 осіб юнацького віку). Дослідження проводилось онлайн за допомогою створених гул форм.

Загальні результати проведеного дослідження показують, що 28 \% учнів та студентів юнацького віку мають низький рівень прояву прокрастинації, 55 \% демонструють середні показники прояву даної якості і 17 \% досліджуваних мають високі показники прояву прокрастинації (рис.2.).

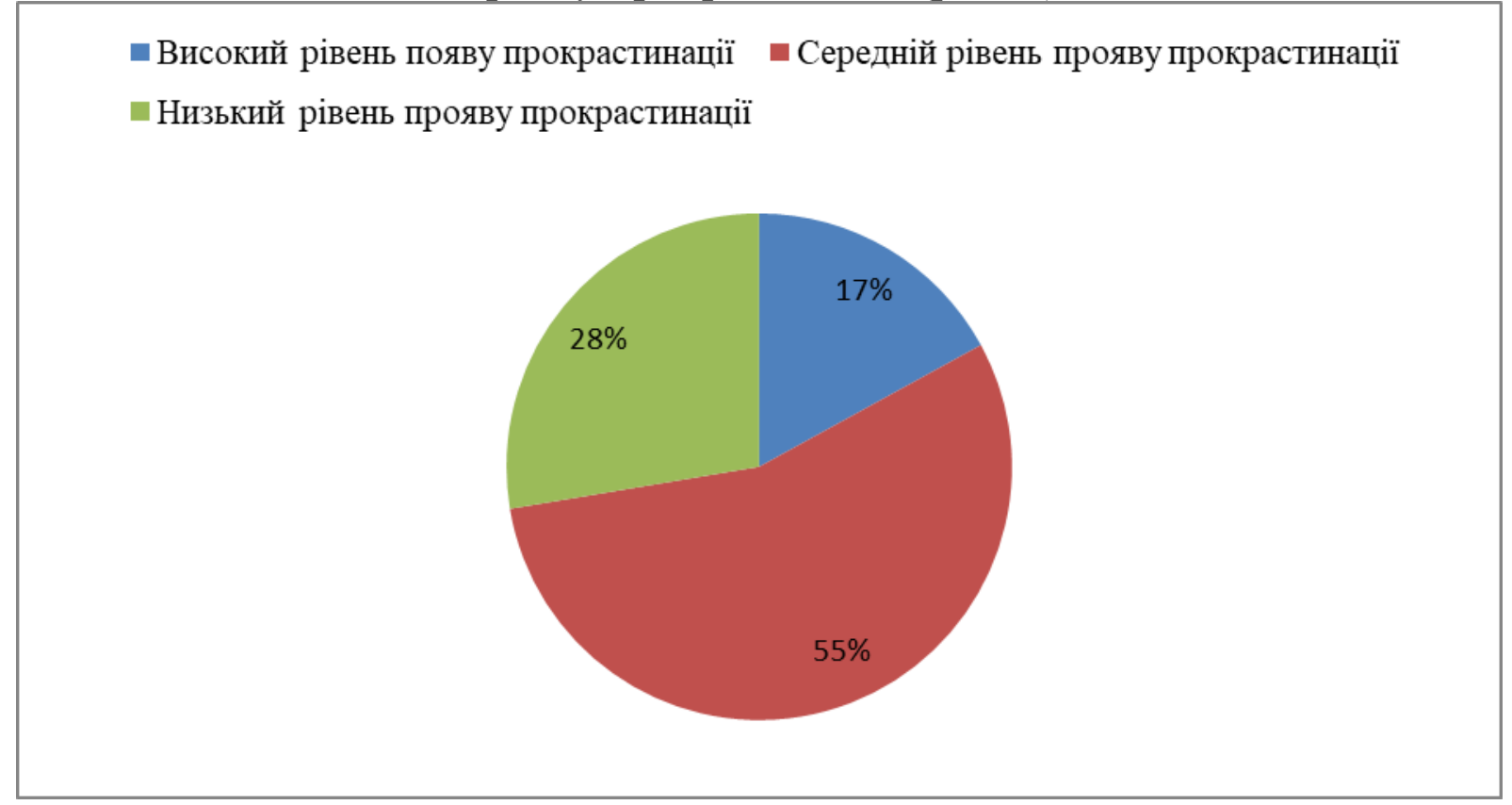

\section{Pис. 2. Результати дослідження}

Таким чином, ми бачимо, що серед юнаків та дівчат є такі, що мають низький рівень прояву прокрастинації. Така молодь дуже рідко відкладає важливі справи «на потім», вони намагаються виконувати справи швидко й у найкоротші терміни. Також є такі, що мають середній рівень і їх найбільше. Такі юнаки та дівчата не зволікають у виконанні важливих справ, а відкладають ії на не великий час, тому що впевнені, що зможуть закінчити цю справу за менший час, ніж було відведено на виконання цього виконання. Ну і $\epsilon$ така молодь юнацького віку, які мають високий рівень прояву прокрастинації. Вони завжди втікають від виконання важливий завдань i пояснюють це тим, що в них є важливіші справи. Їм притаманно дуже довго приймати рішення про те, що потрібно почати виконувати курсову роботу, підготовлюватись до екзамену і виправдовуються тим, що це: невчасно, вони втомилися і в них немає настрою. 
Проведений аналіз вікових особливостей прояву прокрастинації у молодшому та старшому юнацькому віці показав, що відтерміновування важливих справ властиве старшому юнацькому віку (рис.3 та рис.4).

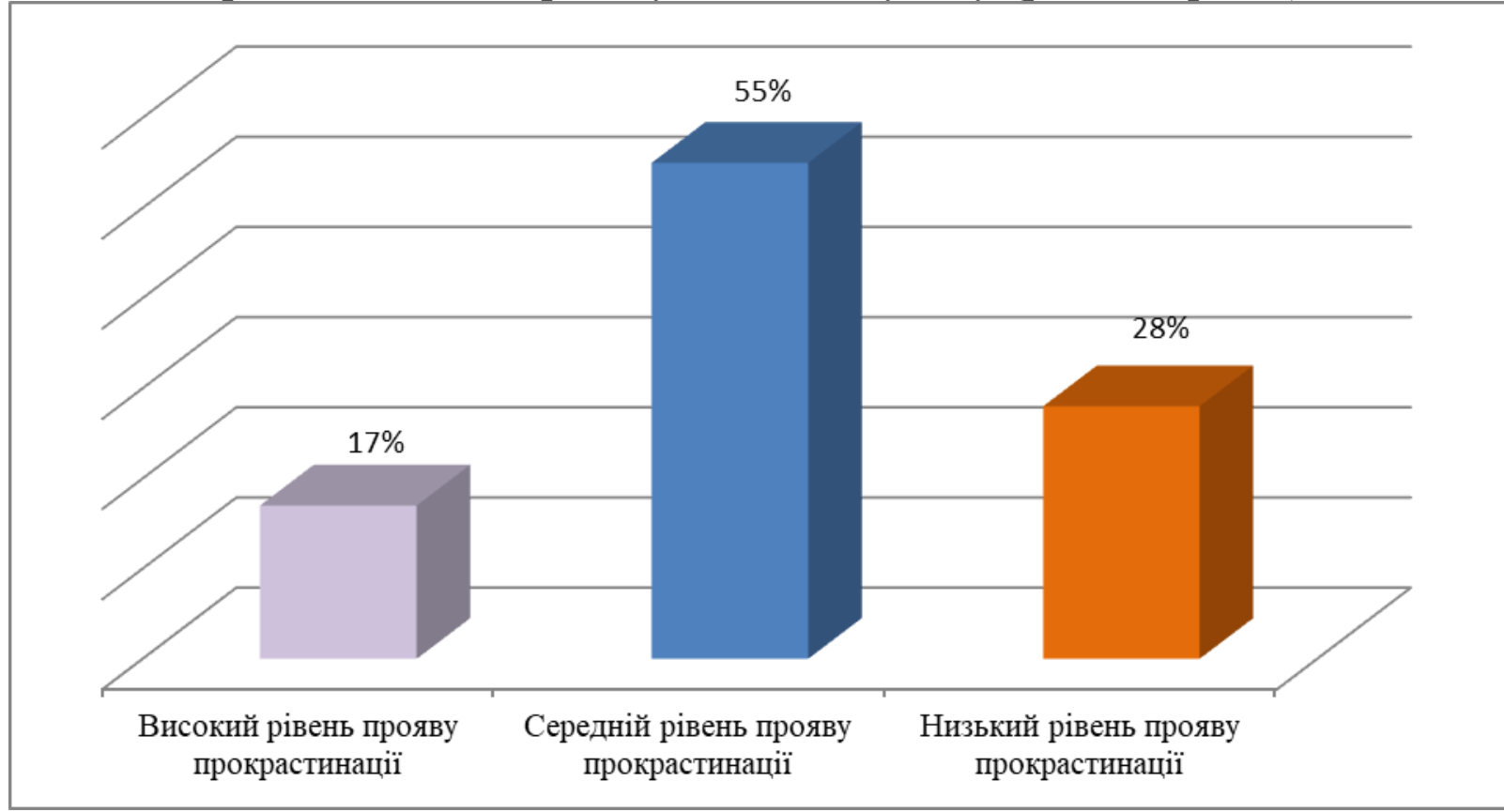

Pис. 3 Результати дослідження рівня прокрастинації молоді старшого юнацького віку

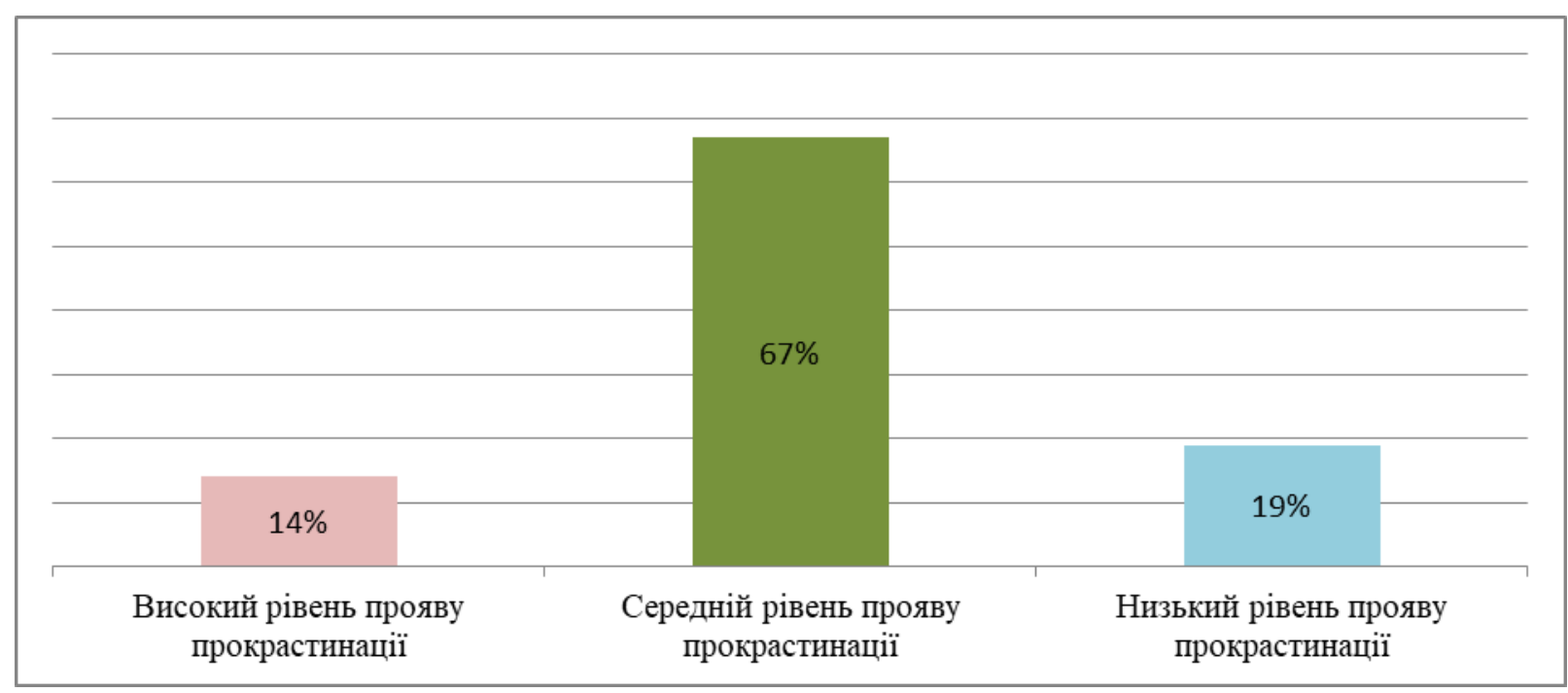

Рис. 4. Результати дослідження рівня прокрастинаиї̈ молоді молодшого юнацького віку

Гендерний аналіз проведеного дослідження показав, що до прокрастинації більш схильні хлопці (рис.5 та рис.6). 
Журнал«Герспективитаінновації наукиљ

(Серія «Гедагогіка», Серія«Гடихологія», Серія«Медицина»

№5(5) 2021

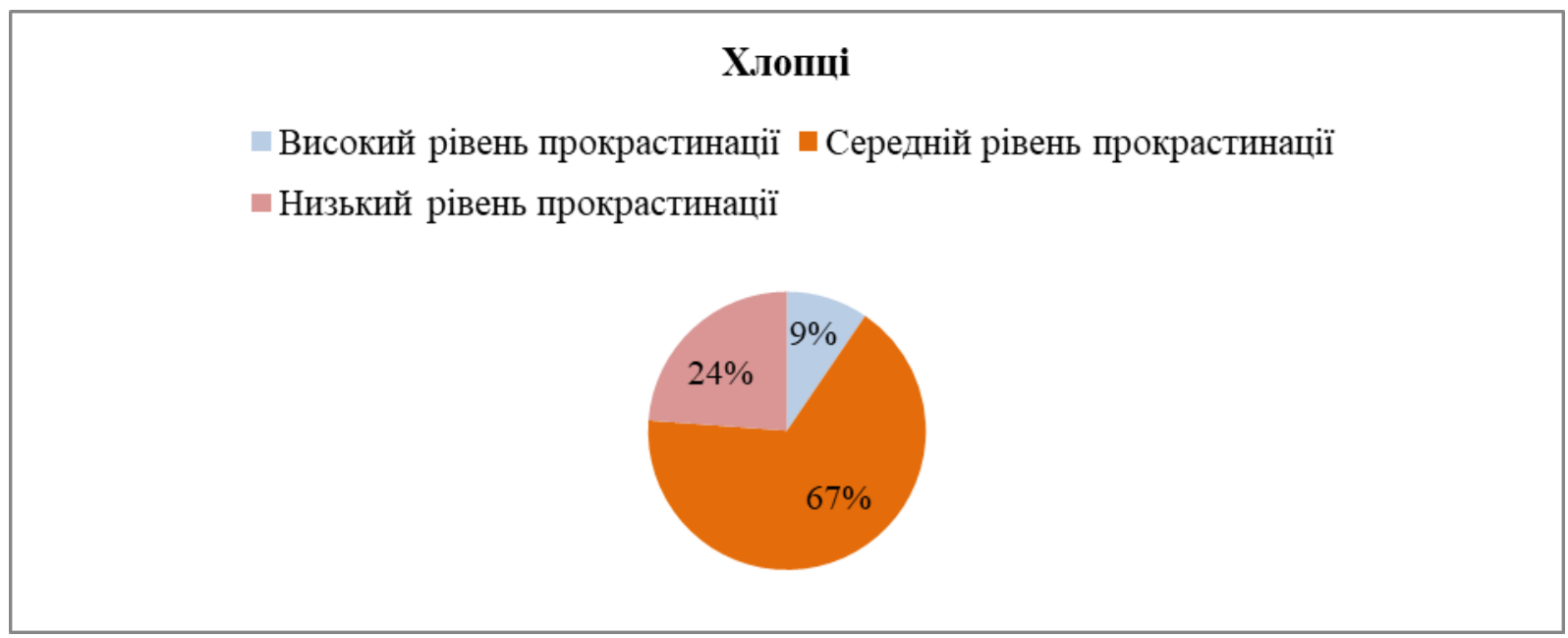

Pис. 5 Результати гендерного аналізу (хлопиі)

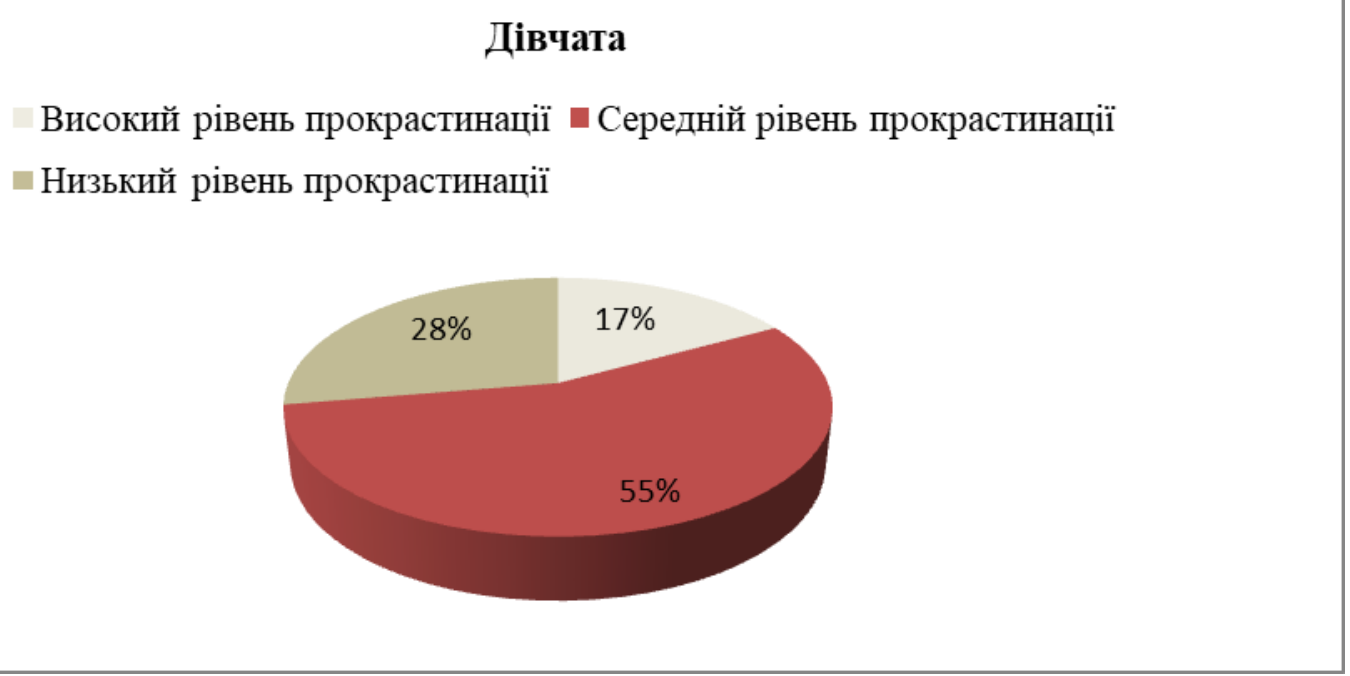

Рис. 6 Результати гендерного аналізу (дівчата)

Висновки. Отже, результати констатувального дослідження довели, що більшість юнаків та дівчат юнацького віку мають середній рівень прояву прокрастинації, але частина досліджуваних потребують додаткової уваги педагогів та фахівців, для подолання проявів прокрастинації.

\section{Лimepamypa:}

1. Варваричева Я. И. Феномен прокрастинации: проблемы и перспективы исследования // Вопросы психологии. № 3 2010, С. 121-131.

2. Словник української мови : в 11 т. Київ : Наукова думка, 1970-1980.

3. Lay C. H. At last, my research article on procrastination // Journal of Research in Personality. Vol. 20 1986, p. 474-495.

4. Мохова С. Б., Неврюев А. Н. Психологические корреляты общей и академической прокрастинации у студентов // Вопросы психологии. №1. 2013, С. 24-35.

5. Шемякина О. О. Влияние прокрастинации на уровень стресса у студентов // Психология $u$ право. 2013. №4. C. 99-109. URL: http://psyjournals.ru/psyandlaw/2013/n4/66242.shtml. 
6. Мотрук Т. О. Прокрастинація як інгібітор розвитку успішної особистості // Актуальні питання сучасної психології. Матеріали I всеукр. наук.-практ. конф. (м. Суми, 15 трав. 2014 р.). Суми 2014, С. 388.

7. Колтунович Т. А. Прокрастинація - конфлікт між «важливим» і «приємним» // Молодий вчений. № 5(45). 2017, С. 211-218.

8. Milgram N. A., Batori G., Mowrer D. Correlates of academic procrastination. // Journal of School Psychology. № 31 1993, pp. 487-500.

9. Milgram N., Tenne R. Personality correlates of decisional and task voidant procrastination. // European Journal of Personality. Vol.14 2000, pp.141-156.

10. Ковылин В. С. Теоретические основы изучения феномена прокрастинации. // Личность в меняюшемся мире: здоровье, адаптаџия, развитие. № 2 (2) 2013, С. 22-41.

\section{References:}

1. Varvarycheva Ya. Y. (2010) Fenomen prokrastynatsyy: problemb y perspektyvы yssledovanyia [The phenomenon of procrastination: problems and prospects of research]. // Voprosy psykholohiyi - Questions of psychology. 121-131. [in Ukrainian].

2. Slovnyk ukrayins'koyi movy [Dictionary of the Ukrainian language]: $\mathrm{v} 11 \mathrm{t}$. Naukova dumka, Kyiv, Ukraine: $1970-1980$.

3. Lay C. H. At last, my research article on procrastination // Journal of Research in Personality. Vol. 20 1986, pp. 474-495.

4. Mokhova S. B., Nevriuev A. N. (2013) Psykholohycheskye korreliatb obshchei y akademycheskoi prokrastynatsyy u studentov [Psychological correlates of general and academic procrastination of students]. // Voprosy psykholohiyi - Questions of psychology. 24-35. [in Ukrainian].

5. Shemiakyna O. O. Vlyianye prokrastynatsyy na uroven stressa u studentov [The influence of procrastination on the level of stress of students]. // Psykholohiya i Pravo - Psychology and Law, available at:: http://psyjournals.ru/psyandlaw/2013/n4/66242.shtml. (access date December 8, 2021)

6. Motruk T. O. (2014) Prokrastynatsiia yak inhibitor rozvytku uspishnoi osobystosti [Procrastination as an inhibitor of successful personality development // Actualni pytannya suchasnoyi psychologiyi - Current issues of modern psychology materials I All-Ukrainian scientific-practical conference] (m. Sumy, 15 trav. 2014 r.). 388. [in Ukrainian].

7. Koltunovych T. A. (2017) Prokrastynatsiia - konflikt mizh «vazhlyvym» i «pryiemnym» [Procrastination is the conflict between "important" and "pleasant"] // Molodiy vcheniy - Young Scientist 211-218. [in Ukrainian].

8. Milgram N. A., Batori G., Mowrer D. Correlates of academic procrastination. // Journal of School Psychology. № 31 1993, pp. 487-500.

9. Milgram N., Tenne R. Personality correlates of decisional and task voidant procrastination. // European Journal of Personality. Vol.14 2000, pp.141-156.

10.Kovylyn V. S. Teoretycheskiye osnovy izucheniya fenomena prokrastynatsiyi.[Theoretical bases of studying the phenomenon of procrastination]. Lychnost $v$ meniaiushchemsia myre: zdorovye, adaptatsyia, razvytiye - Personality in a changing world: health, adaptation, development 22-41. [in Ukrainian]. 